CLINICAL STUDY

\title{
Serum osteoprotegerin concentrations are decreased in women with the polycystic ovary syndrome
}

\author{
Héctor F Escobar-Morreale ${ }^{1}$, José I Botella-Carretero ${ }^{1}, \mathrm{M}^{\mathrm{a}}$ Ángeles Martínez-García ${ }^{1}$, Manuel Luque-Ramírez ${ }^{1}$, \\ Francisco Álvarez-Blasco ${ }^{1}$ and José L San Millán ${ }^{2}$ \\ Departments of ${ }^{1}$ Endocrinology and ${ }^{2}$ Molecular Genetics, Hospital Ramón y Cajal \& Universidad de Alcalá, and Centro de Investigación Biomédica en Red \\ Diabetes y Enfermedades Metabólicas Asociadas (CIBERDEM), Instituto de Salud Carlos III, Spanish Ministry of Science and Innovation, \\ 28034 Madrid, Spain \\ (Correspondence should be addressed to H F Escobar-Morreale who is now at Department of Endocrinology, Hospital Universitario Ramón y Cajal E \\ Universidad de Alcalá, Carretera de Colmenar Km. 9.1, 28034 Madrid, Spain; Email: hescobarm.hrc@salud.madrid.org)
}

\begin{abstract}
Objective: Osteoprotegerin (OPG), an inhibitor of osteoclastic bone resorption, has a variety of functions including anti-inflammatory effects and a possible cardiovascular protective role. Both low-grade chronic inflammation and cardiovascular risk are increased in women with the polycystic ovary syndrome (PCOS). We aimed to study serum OPG concentrations in PCOS patients.

Design: Case-control study including 40 PCOS patients matched with 40 non-hyperandrogenic women for age and body mass index.

Methods: Basal serum sampling and standard oral glucose tolerance test, and measurement of serum OPG concentrations by commercial ELISA.

Results: Serum OPG concentrations were lower in women with PCOS compared with those of controls $(304 \pm 120$ vs $363 \pm 105 \mathrm{pg} / \mathrm{ml}$ respectively; $F=7.641, P=0.007)$ independently of obesity. No differences were observed in serum receptor activator of nuclear factor- $\kappa \mathrm{B}$ ligand (RANKL) levels and in the RANKL/OPG molar ratio. A multivariate linear regression model $\left(R^{2}=0.208, F=6.579\right.$, $P=0.001)$ showed that $\operatorname{PCOS}(\beta=-0.281, P=0.008)$, obesity $(\beta=-0.245, P=0.022)$ and age $(\beta=0.296, P=0.006)$ were predictive of serum OPG concentrations.

Conclusions: Serum OPG concentrations are reduced in PCOS patients independently of obesity. Considering the anti-inflammatory effects of OPG, its reduced serum concentrations might contribute to the proinflammatory state and cardiovascular risk of PCOS patients.
\end{abstract}

European Journal of Endocrinology $159225-232$

\section{Introduction}

The polycystic ovary syndrome (PCOS) is one of the most common endocrine disorders, affecting $6.5 \%$ of women of fertile age in Spain (1). Over past years, a chronic proinflammatory state has been associated with hyperandrogenism and PCOS (2). On the one hand, increased serum C-reactive protein concentrations have been reported in PCOS patients (3). On the other hand, we have shown that common polymorphisms in the genes encoding tumour necrosis factor (TNF)- $\alpha$, type 2 TNF receptor, interleukin (IL)-6, and the IL-6 signaling molecule gp130 are associated with hyperandrogenism and PCOS, or influence hyperandrogenic phenotypic traits (4-7). Moreover, we have also shown that circulating IL-18, another proinflammatory cytokine, is increased in women presenting with hyperandrogenism and PCOS, correlating with body mass index (BMI) and with the degree of insulin resistance (8).

Serum markers of inflammation are being increasingly recognized as predictors of atherosclerosis and cardiovascular disease $(9,10)$. The increased concentration of these inflammatory markers clusters with classic cardiovascular risk factors - including obesity, dyslipidemia, glucose intolerance, type 2 diabetes, and hypertension - in some patients. In fact, chronic lowgrade inflammation has been proposed to play a role in the pathogenesis of insulin resistance and the subsequent development of cardiovascular disease $(11,12)$.

Osteoprotegerin $(\mathrm{OPG})$ is a member of the tumor necrosis factor receptor superfamily and is a secretory basic glycoprotein that exists in a $60 \mathrm{kDa}$ monomeric form and a disulfide-linked homodimeric form of $120 \mathrm{kDa}(13,14)$. OPG is produced in many different tissues and cell types $(13,14)$ and, by binding and neutralizing the receptor activator of nuclear factor- $\kappa \mathrm{B}$ ligand (RANKL), exerts an inhibitory effect on osteoclastic bone resorption (15).

Besides, OPG has other biological functions, including anti-inflammatory actions, such as an anti-apoptotic effect resulting from the binding of TNF-related apoptosis-inducing ligand (TRAIL) with a consequent inhibition of the apoptosis process of susceptible 
cells (16). Interestingly, endothelial cells are one of the sites in which the anti-apoptotic effects of OPG have been demonstrated $(17,18)$, suggesting a protective vascular role of the latter (19). Therefore, OPG has, apart from the aforementioned effects on osteoclastogenesis, other functions in vascular processes and immune responses that may be relevant to the pathogenesis of PCOS and its associated co-morbidities.

Recently published data show that obesity and insulin resistance result in a decrease in serum OPG concentrations $(20,21)$. However, to our knowledge, no studies have been published so far addressing serum OPG and RANKL concentrations in PCOS patients.

\section{Materials and methods}

\section{Subjects}

For the present case-control study, 40 PCOS patients and 40 non-hyperandrogenic women, matched for age and BMI, were recruited. The diagnosis of PCOS was established according to the criteria derived from the 1990 National Institute of Child Health and Human Development (NICHD) conference (22). Specifically, PCOS was defined by oligo-ovulation, clinical and/or biochemical hyperandrogenism, and exclusion of hyperprolactinemia (serum prolactin below $24 \mathrm{ng} / \mathrm{ml}(24 \mu \mathrm{g} / \mathrm{l})$ ), non-classic congenital adrenal hyperplasia (basal 17-hydroxyprogesterone levels below $1.7 \mathrm{ng} / \mathrm{ml}$ (5.1 nmol/l) (23)), androgen-secreting tumors, and thyroid dysfunction (thyrotropin between 0.35 and $4.5 \mu \mathrm{U} / \mathrm{ml}$ ). Evidence for oligo-ovulation was provided by chronic oligomenorrhea or, in regularly menstruating women, by luteal phase progesterone below $4 \mathrm{ng} / \mathrm{ml}$ (12.7 nmol/l) or by basal body temperature charts. All the control premenopausal women had no clinical or biochemical evidence of hyperandrogenism and had regular menstrual cycles. None of the patients or controls had received chronic pharmacological therapy with any drug for the previous 6 months. The ethics committee of the Hospital Ramón y Cajal approved the protocol, and informed consent was obtained from each woman.

\section{Anthropometrics and analytical parameters}

Clinical and anthropometrical variables, including a modified hirsutism score (24), BMI, and waist-to-hip ratio were determined by a single investigator in all the subjects. The minimal waist circumference was recorded using a non-stretchable measuring tape. Patients and controls were classified according to their BMI into nonobese $\left(\mathrm{BMI}<30 \mathrm{~kg} / \mathrm{m}^{2}\right)$ or obese $\left(\mathrm{BMI} \geq 30 \mathrm{~kg} / \mathrm{m}^{2}\right)$ subgroups. Office blood pressure was determined in every patient as the mean of two manual sphygmomanometer readings at the sitting position.

Serum and plasma samples were obtained between days 5 and 10 of the menstrual cycle or during amenorrhea after excluding pregnancy. After a 3-day $300 \mathrm{~g}$ carbohydrate diet and a 12-h overnight fasting, samples were obtained early in the morning for the measurement of total testosterone, 17-hydroxyprogesterone, sex hormone-binding globulin (SHBG), androstenedione, DHEA-sulfate, luteinizing hormone, follicle-stimulating hormone, estradiol, prolactin, and thyrotropin. Complete serum biochemistry and lipid profiles were also obtained. Then, a $75 \mathrm{~g}$ oral glucose tolerance test was performed, and samples were obtained for measurement of serum insulin and plasma glucose at $0,30,60,90$, and $120 \mathrm{~min}$. Samples were immediately centrifuged, and serum was separated and frozen at $-30{ }^{\circ} \mathrm{C}$ until assayed.

Serum OPG concentrations were measured in duplicate using a commercial ELISA (RayBiotech Inc., Norcross, GA, USA). The sensitivity of the assay was $1 \mathrm{pg} / \mathrm{ml}$ $(0.018 \mathrm{pmol} / \mathrm{l})$ and the mean intra- and inter-assay coefficients of variation were below $10 \%$. Serum RANKL levels were measured in duplicate using a commercial enhanced ELISA (ampli sRANKL human, Biomedica Gruppe, Vienna, Austria). The assay was run in parallel using two plates, each containing its own standard curve. We added two standard concentrations, containing 0.625 and $1.25 \mathrm{pg} / \mathrm{ml}$, to the $0,2.5,5,10,20$, and $40 \mathrm{pg} / \mathrm{ml}$ standard concentrations provided with the kit. The fourparameter standard curves resulting from the measurement of these standard concentrations had coefficients of determination $\left(R^{2}\right)$ of 0.99959 and 0.99924 , and the measurement of the internal quality control provided with the $\mathrm{kit}$ was $5.7 \mathrm{pg} / \mathrm{ml}$ (reference value $5.8 \mathrm{pg} / \mathrm{ml} \pm$ s.D. $1.8 \mathrm{pg} / \mathrm{ml}$ ). Following the indications of the manufacturer's insert, and as has been done in recent studies (25), values less than the $0.625 \mathrm{pg} / \mathrm{ml}$ standard concentration were extrapolated from the four-parameter curves. The lowest detectable serum RANKL concentration was $0.075 \mathrm{pg} / \mathrm{ml}$, and undetectable values were set at $0.075 \mathrm{pg} / \mathrm{ml}$ for statistical analysis. The mean intraand inter-assay coefficients of variation, as reported by the manufacturer, were below $10 \%$. The molar serum RANKL/OPG molar ratio was calculated after converting the serum RANKL and OPG metric concentrations (molecular weights 20 and $55 \mathrm{kDa}$ respectively) to pmol/l.

The technical characteristics of the assays employed for plasma glucose, lipid profile and serum hormone measurements have been described elsewhere $(8,26$, 27). The free testosterone (FT) concentration was calculated from total testosterone and SHBG concentrations (28). The composite insulin sensitivity index was calculated from the circulating glucose and insulin concentrations during the oral glucose tolerance test according to Matsuda \& DeFronzo (29).

\section{Statistical analysis}

Results are expressed as means \pm s.D. unless otherwise stated. The Kolmogorov-Smirnov statistic was applied to continuous variables. Logarithmic or square root 
transformations were applied as needed to ensure a normal distribution of continuous variables.

Comparisons of continuous variables between two groups were done by independent sample $t$-test and for categorical data by the $\chi^{2}$-test or Fisher's exact test, as appropriate. To analyze the effects of PCOS, obesity, and their interaction, on serum OPG and RANKL concentrations, two-way ANOVA was employed to avoid type 1 errors arising from multiple comparisons.

The relationship between continuous variables was assessed by Pearson's correlation analysis. Finally, a stepwise (probability of $F$ to enter $\leq 0.05$, probability of $F$ to remove $\geq 0.10$ ) multiple linear regression model was used to evaluate the influence of several independent variables on serum OPG concentrations. Analyses were performed using SPSS 10 for Macintosh (SPSS Inc., Chicago, IL, USA). $P<0.05$ was considered statistically significant.

\section{Results}

The clinical and biochemical characteristics of the PCOS patients and non-hyperandrogenic controls are shown in Table 1. Compared with the controls, PCOS patients presented with higher hirsutism score, serum total and FT, androstenedione, DHEA-sulfate, and triglyceride concentrations, whereas their serum SHBG, estradiol and high-density lipoprotein cholesterol concentrations, and their insulin sensitivity index were reduced (Table 1 ).
As expected from appropriate matching, no differences were observed among PCOS patients and control women in age, BMI, frequency of obesity, and frequency of smokers (Table 1).

Serum OPG concentrations were lower in PCOS patients compared with those of non-hyperandrogenic control women $(304 \pm 120$ and $363 \pm 105 \mathrm{pg} / \mathrm{ml}$ respectively, $F=7.641, P=0.007$, Fig. 1), whereas obesity showed a borderline non-significant lowering effect on serum OPG concentrations $(F=3.045$, $P=0.085$, Fig. 1). Furthermore, the effects of PCOS and obesity were independent, because their interaction had no statistically significant effects on serum OPG concentrations $(F=0.001, P=0.974$, Fig. 1). PCOS patients and controls presented with similar serum RANKL levels $(1.04 \pm 0.83$ vs $1.43 \pm 1.46 \mathrm{pg} / \mathrm{ml}$, $F=1.398, P=0.241$; Fig. 1$)$ and serum RANKL/OPG molar ratios $(0.012 \pm 0.011$ vs $0.012 \pm 0.013$, $F=0.010, P=0.922$, Fig. 1$)$, and these variables were also similar in non-obese and obese women $(F=0.048$, $P=0.828$ for serum RANKL levels and $F=0.124$, $P=0.725$, for serum RANKL/OPG molar ratio; Fig. 1).

Serum OPG concentrations showed weak but statistically significant direct correlations with age $(r=0.258$, $P=0.021)$ and serum SHBG concentrations $(r=0.285$, $P=0.010)$, and inverse correlations with the hirsutism score $(r=-0.360, P=0.001)$ and with serum-FT levels ( $r=-0.274, P=0.014$; Fig. 2).

Considering that women with PCOS differed with respect to the non-hyperandrogenic control women in several variables, such as serum androgens, estradiol,

Table 1 Clinical and biochemical variables of the polycystic ovary syndrome (PCOS) patients and controls.

\begin{tabular}{|c|c|c|c|}
\hline & $\operatorname{Pcos}(n=40)$ & Controls $(n=40)$ & $P$ value \\
\hline Smokers $(n(\%))$ & $9(22.5)$ & $11(27.5)$ & 0.606 \\
\hline Age (years) & $26.2 \pm 5.7$ & $26.6 \pm 6.0$ & 0.732 \\
\hline Obese/non-obese ( $n(\%))$ & $19(47.5) / 21(52.5)$ & $19(47.5) / 21(52.5)$ & 0.995 \\
\hline Body mass index $\left(\mathrm{kg} / \mathrm{m}^{2}\right)$ & $29.0 \pm 5.6$ & $29.2 \pm 6.5$ & 0.918 \\
\hline Waist circumference $(\mathrm{cm})$ & $84 \pm 14$ & $83 \pm 13$ & 0.922 \\
\hline Hirsutism score & $10 \pm 6$ & $2 \pm 2$ & $<0.001$ \\
\hline Systolic blood pressure (mmHg) & $112 \pm 12$ & $112 \pm 12$ & 0.955 \\
\hline Diastolic blood pressure $(\mathrm{mmHg})$ & $70 \pm 10$ & $69 \pm \overline{7}$ & 0.623 \\
\hline Fasting glucose (mg/dl) & $93 \pm 11$ & $93 \pm 13$ & 0.841 \\
\hline Fasting insulin $(\mu \mathrm{U} / \mathrm{ml})$ & $12.3 \pm 12.1$ & $7.6 \pm 4.7$ & 0.110 \\
\hline Insulin sensitivity index & $5.8 \pm 4.9$ & $7.1 \pm 4.4$ & 0.025 \\
\hline Total testosterone $(\mathrm{ng} / \mathrm{dl})$ & $57 \pm 20$ & $40 \pm 13$ & $<0.001$ \\
\hline Free testosterone $(\mathrm{ng} / \mathrm{dl})$ & $1.2 \pm 0.6$ & $0 . \overline{ \pm} \pm 0.3$ & $<0.001$ \\
\hline Sex hormone-binding globulin $(\mu \mathrm{g} / \mathrm{dl})$ & $302 \pm 169$ & $379 \pm 175$ & 0.049 \\
\hline Androstenedione $(\mathrm{ng} / \mathrm{ml})$ & $3.3 \pm 1.3$ & $2.5 \pm 0.9$ & 0.001 \\
\hline DHEA-sulfate $(\mathrm{ng} / \mathrm{ml})$ & $2095 \pm 1018$ & $1631 \pm 798$ & 0.026 \\
\hline Estradiol $(\mathrm{pg} / \mathrm{ml})$ & $48 \pm 42$ & $66 \pm 77$ & 0.048 \\
\hline Luteinizing hormone $(\mathrm{mU} / \mathrm{ml})$ & $5.9 \pm 5.0$ & $4.9 \pm 2.6$ & 0.234 \\
\hline Follicle-stimulating hormone $(\mathrm{mU} / \mathrm{ml})$ & $4.8 \pm 1.7$ & $5.2 \pm 1.3$ & 0.202 \\
\hline Cholesterol (mg/dl) & $172 \pm 33$ & $176 \pm 31$ & 0.586 \\
\hline High-density lipoprotein cholesterol (mg/dl) & $45 \pm 11$ & $52 \pm 13$ & 0.010 \\
\hline Low-density lipoprotein cholesterol (mg/dl) & $106 \pm 26$ & $110 \pm 26$ & 0.496 \\
\hline Trialycerides $(\mathrm{mg} / \mathrm{dl})$ & $111+87$ & $70+24$ & 0.010 \\
\hline
\end{tabular}

Data are means \pm S.D. unless otherwise stated. To convert to $\mathrm{SI}$ units, multiply glucose by 0.555 (result in mmol/l), insulin by 6.945 (result in pmol/l), total testosterone by 0.03467 (result in nmol/l), free testosterone by 34.67 (result in pmol/l), sex hormone-binding globulin by 0.111 (result in nmol/l), androstenedione by 3.49 (result in nmol/l), DHEA-sulfate by 0.002714 (result in $\mu \mathrm{mol} / \mathrm{l}$ ), estradiol by 3.671 (result in pmol/l), gonadotropins by 1 (result in UI/l), cholesterol by 0.0259 (result in $\mathrm{mmol} / \mathrm{l}$ ), and triglycerides by 0.0113 (result in $\mathrm{mmol} / \mathrm{l}$ ). 
and lipids, multivariate linear regression was performed to search for any variables that may be associated with serum OPG concentrations and also to correct for possible confounding effects. Serum OPG concentration was introduced as the dependent variable, whereas PCOS status, presence of obesity, age, serum-FT, androstenedione, DHEA-sulfate, estradiol, high-density lipoprotein cholesterol, and triglycerides concentrations were introduced as independent variables.
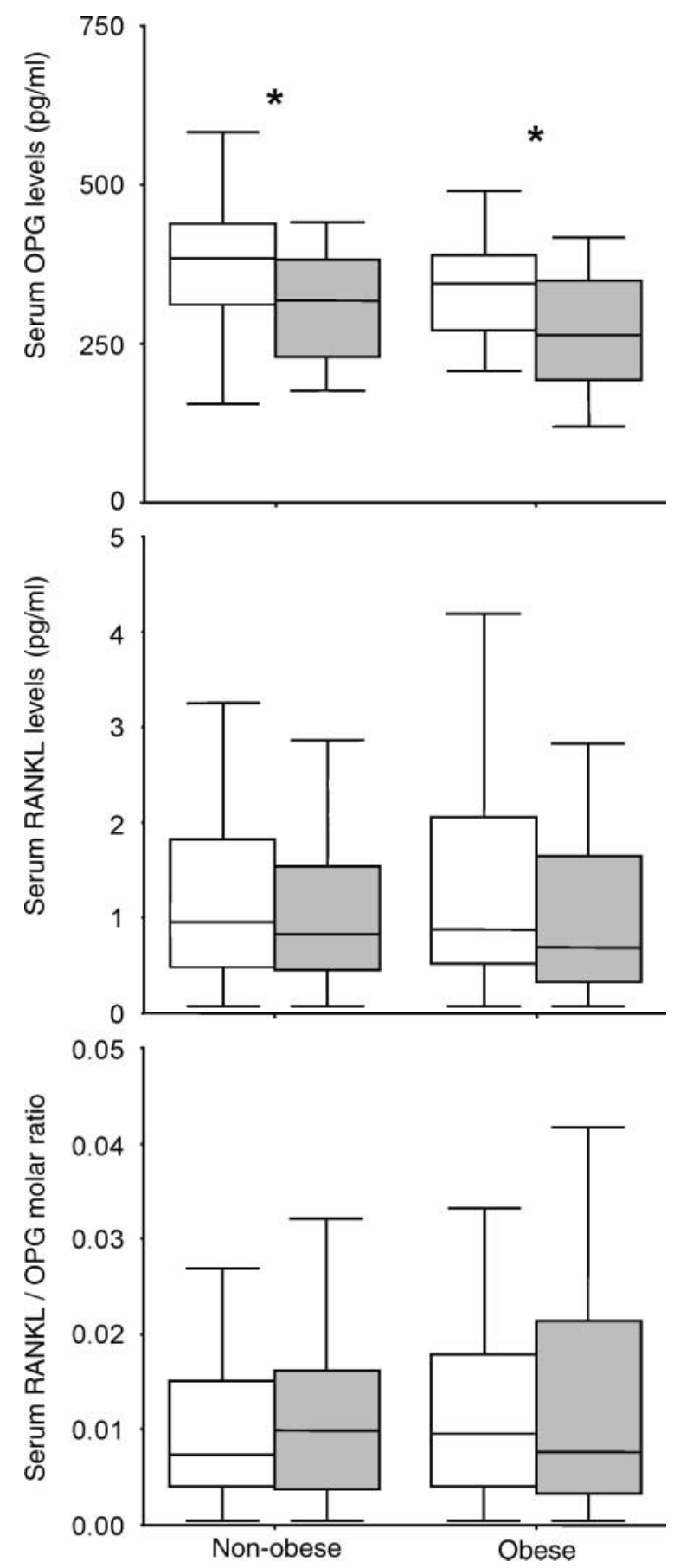

The model $\left(R^{2}=0.208, \quad F=6.579, \quad P=0.001\right)$ showed that $\operatorname{PCOS}(\beta=-0.281, P=0.008)$, obesity $(\beta=-0.245, \quad P=0.022), \quad$ and age $(\beta=0.296$, $P=0.006)$ were statistically significant determinants of serum OPG concentrations, meaning that $20.8 \%$ of the variation in serum OPG levels was explained by the variation in these three variables. On the contrary, the addition to the model of the insulin sensitivity index and waist circumference as independent variables did not result in any significant changes (data not shown). When BMI was introduced as the independent variable instead of the presence of obesity, the model $\left(R^{2}=0.170\right.$, $F=6.545, P=0.002)$ only retained $P C O S(\beta=-0.318$, $P=0.004)$ as a statistically significant predictor of serum OPG concentrations, whereas BMI $(\beta=-0.143$, $P=0.108)$ and age $(\beta=0.192, P=0.078)$ were excluded.

\section{Discussion}

Our present results show for the first time that serum OPG concentrations are reduced in PCOS patients and that this finding is independent from obesity. Furthermore, according to the results of the regression analysis, our data confirm that obesity has a negative impact on serum OPG levels in premenopausal women, as has been reported in two previous studies conducted in different populations $(20,21)$.

The reduction of serum OPG in PCOS and obesity might be related to the increased cardiovascular risk associated with these disorders, given that OPG may play a protective role in the vasculature by both inhibition of RANKL and TRAIL, preventing plaque complication and apoptosis of endothelial cells. On one hand, by failing to neutralize RANKL, reduced OPG levels might favor cardiovascular disease, because RANKL overexpression is a prominent feature prone to rupture vulnerable atherosclerotic lesions, RANKL may also contribute to the transition from a stable to an unstable plaque (30), and the serum level of RANKL is a highly significant predictor of cardiovascular disease (31). However, it must be noted that neither serum RANKL levels nor the serum RANKL/OPG molar ratio were different in our PCOS patients compared with the non-hyperandrogenic

Figure 1 Serum osteoprotegerin (OPG) and RANKL concentrations, and the serum RANKL/OPG molar ratio, in obese and nonobese PCOS patients (grey boxes) and non-hyperandrogenic controls (white boxes). The box plot includes the median (horizontal line) and the interquartile range (box), and the whiskers indicate the minimum and maximum data values, unless outliers are present in which case the whiskers extend to a maximum of 1.5 times the interquartile range. ${ }^{*} P=0.007$ between $\mathrm{PCOS}$ patients and healthy controls by two-way ANOVA. There was a near-significant difference in serum OPG concentrations between obese and lean women $(P=0.085)$, whereas no statistically significant interaction between PCOS and obesity was observed $(P=0.974)$. Neither PCOS nor obesity showed statistically significant influences on serum RANKL levels and on the serum RANKL/OPG molar ratio. 

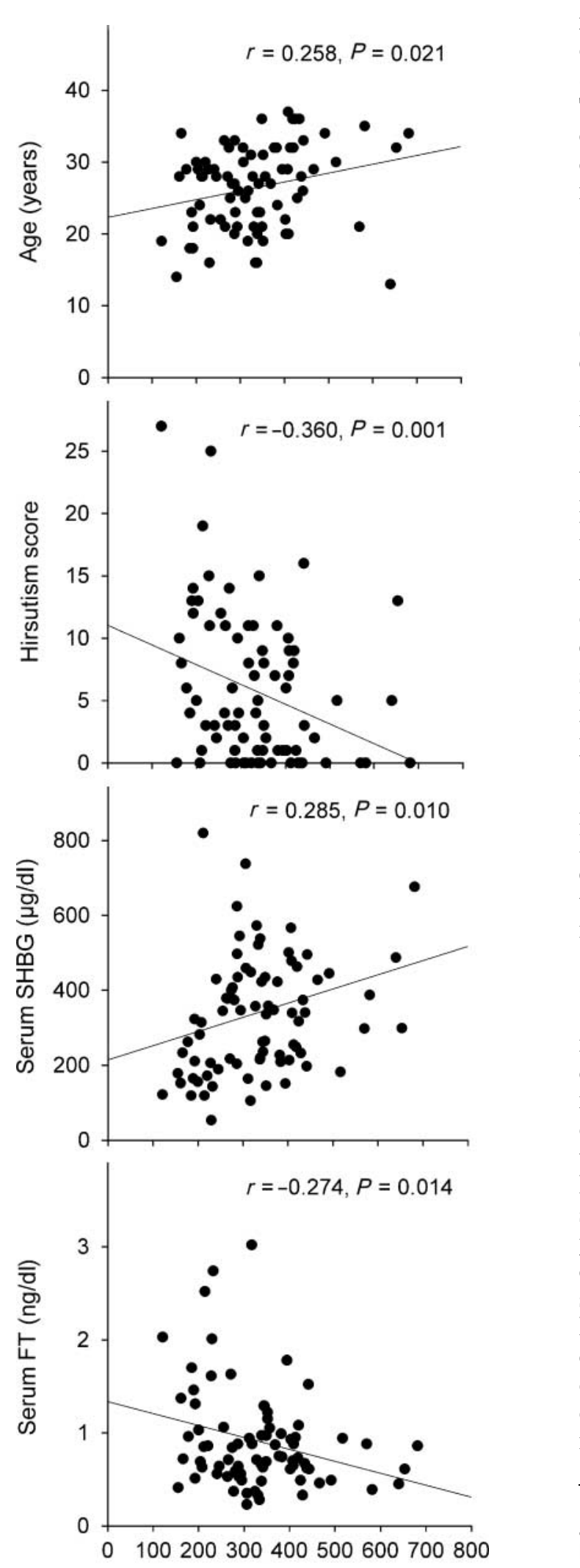

Serum osteoprotegerin $(\mathrm{pg} / \mathrm{ml})$ controls, suggesting that the possible consequences of reduced OPG concentrations in PCOS may be independent of an actual increase in serum RANKL concentrations and availability. On the other hand, a less effective inhibition of TRAIL resulting from the reduction in serum OPG concentrations could also favor the development of cardiovascular disease in PCOS patients, because TRAIL facilitates apoptosis, and apoptosis initiates mineralization (32), macrophage recruitment, and inflammation on atherosclerotic plaques, resulting in intimal calcification $(11,19)$.

In conceptual agreement with a role of decreased OPG levels in the development of cardiovascular disease, animal models showed an accelerated progression of atherosclerotic lesions with calcification in mice lacking OPG (33), OPG knockout mice display arterial calcification (34), and parenteral administration of OPG in rats prevents the vascular calcification induced by treatment with warfarin and supraphysiological doses of vitamin D (35).

However, increased circulating OPG levels have also been found in association with the presence and severity of coronary artery disease (36-38), peripheral artery disease (39), and stroke (40), suggesting that OPG may serve as a biomarker of established atherosclerosis in humans $(41,42)$. The apparent paradox of increased levels of a cardiovascular protective molecule in subjects with established atherosclerotic disease may result from a local compensatory response to atherosclerosis. Yet it is also equally possible that $\mathrm{OPG}$, when present in very high concentrations (subjects with atherosclerotic disease show a fivefold increase in serum OPG compared with the young women included in our study) may indeed play a pathogenic role in cardiovascular disease (41) derived from putative pro-inflammatory and proatherosclerotic effects $(43,44))$.

For the reasons explained above, the actual mechanisms underlying the decrease in serum OPG concentrations in PCOS patients remain unknown. We might speculate that the lower levels of estradiol observed in our PCOS women when compared with the controls could have been one of the pathophysiological factors involved, because estradiol has been shown to upregulate OPG gene expression and production $(45,46)$. However, we did not find any correlation between serum estradiol concentrations and serum OPG levels in our study. On the other hand, FT levels were inversely correlated with serum OPG concentrations in our series and could have been one of the involved factors in its reduction $(47,48)$. Yet other authors have found that testosterone may indeed increase OPG expression (49) and it correlates positively

Figure 2 Correlation of serum osteoprotegerin concentrations with age, hirsutism score, serum free testosterone (FT), and sex hormone-binding globulin (SHBG) levels. The scatter plot shows individual data and the regression lines show the bivariate linear relationship of variables, as analyzed by Pearson's correlation. 
with serum OPG concentrations in men (50). Besides, in our study, testosterone levels were not retained as a predictive variable in the multivariate analysis. Finally, insulin resistance, another common characteristic of PCOS patients, has been shown to correlate either directly (51) or inversely (20) with serum OPG concentrations, but we did not find any statistically significant relationship between serum OPG levels and the insulin sensitivity index.

Our study is limited because we did not evaluate bone metabolism in our patients, and OPG concentrations have been shown to be increased in women with osteoporosis when compared with age-matched controls, especially in women with higher bone turnover $(52,53)$. However, it must be noted that the patients included in the present study were all young premenopausal women, with very low risk for osteoporosis, and patients and controls were matched for age, BMI, and smoking habit. Besides, it is not yet clear whether PCOS is associated with lower bone mineral density than healthy individuals (54), especially when there are no other concomitant risk factors for osteoporosis, bone mineral density might be even increased (55). Therefore, we do not believe that our present results could have been biased by differences in bone metabolism between patients and controls.

In conclusion, serum OPG concentrations are reduced in PCOS patients independently of obesity and in the absence of statistically significant changes in serum RANKL levels and in the serum RANKL/OPG molar ratio. Future studies should address the precise pathophysiological roles of the reduced serum OPG concentration observed in PCOS.

\section{Acknowledgements}

We thank Ms Genoveva González from the Laboratory of the Department of Endocrinology of Hospital Ramón y Cajal, for excellent technical help. This study was supported by the Instituto de Investigación Carlos III, grants FIS PI050341 and REDIMET RD06/0015/0007. Centro de Investigación Biomédica en Red Diabetes y Enfermedades Metabólicas Asociadas is an initiative of Instituto de Investigación Carlos III.

\section{References}

1 Asuncion M, Calvo RM, San Millan JL, Sancho J, Avila S \& Escobar-Morreale HF. A prospective study of the prevalence of the polycystic ovary syndrome in unselected Caucasian women from Spain. Journal of Clinical Endocrinology and Metabolism 2000 85 2434-2438.

2 Escobar-Morreale HF, Luque-Ramirez M \& San Millan JL. The molecular-genetic basis of functional hyperandrogenism and the polycystic ovary syndrome. Endocrine Reviews $2005 \mathbf{2 6}$ 251-282.
3 Kelly CC, Lyall H, Petrie JR, Gould GW, Connell JM \& Sattar N. Low grade chronic inflammation in women with polycystic ovarian syndrome. Journal of Clinical Endocrinology and Metabolism 2001 $862453-2455$.

4 Escobar-Morreale HF, Calvo RM, Villuendas G, Sancho J \& San Millan JL. Association of polymorphisms in the interleukin 6 receptor complex with obesity and hyperandrogenism. Obesity Research 200311 987-996.

5 Villuendas G, San Millan JL, Sancho J \& Escobar-Morreale HF. The $-597 \mathrm{G} \rightarrow \mathrm{A}$ and $-174 \mathrm{G} \rightarrow \mathrm{C}$ polymorphisms in the promoter of the IL- 6 gene are associated with hyperandrogenism. Journal of Clinical Endocrinology and Metabolism $2002 \mathbf{8 7}$ 1134-1141.

6 Peral B, San Millan JL, Castello R, Moghetti P \& EscobarMorreale HF. The methionine 196 arginine polymorphism in exon 6 of the TNF receptor 2 gene (TNFRSF1B) is associated with the polycystic ovary syndrome and hyperandrogenism. Journal of Clinical Endocrinology and Metabolism 200287 3977-3983.

7 Escobar-Morreale HF, Calvo RM, Sancho J \& San Millan JL. TNF- $\alpha$ and hyperandrogenism: a clinical, biochemical, and molecular genetic study. Journal of Clinical Endocrinology and Metabolism 2001 $863761-3767$.

8 Escobar-Morreale HF, Botella-Carretero JI, Villuendas G, Sancho J \& San Millan JL. Serum interleukin-18 concentrations are increased in the polycystic ovary syndrome: relationship to insulin resistance and to obesity. Journal of Clinical Endocrinology and Metabolism 200489 806-811.

9 Danesh J, Wheeler JG, Hirschfield GM, Eda S, Eiriksdottir G, Rumley A, Lowe GD, Pepys MB \& Gudnason V. C-reactive protein and other circulating markers of inflammation in the prediction of coronary heart disease. New England Journal of Medicine 2004350 1387-1397.

10 Frishman WH. Biologic markers as predictors of cardiovascular disease. American Journal of Medicine 1998 104 18S-27S.

11 Fernandez-Real JM \& Ricart W. Insulin resistance and chronic cardiovascular inflammatory syndrome. Endocrine Reviews 2003 24 278-301.

12 Dandona P, Aljada A, Chaudhuri A, Mohanty P \& Garg R. Metabolic syndrome: a comprehensive perspective based on interactions between obesity, diabetes, and inflammation. Circulation 2005 111 1448-1454.

13 Simonet WS, Lacey DL, Dunstan CR, Kelley M, Chang MS, Luthy R, Nguyen HQ, Wooden S, Bennett L, Boone T, Shimamoto G, DeRose M, Elliott R, Colombero A, Tan HL, Trail G, Sullivan J, Davy E, Bucay N, Renshaw-Gegg L, Hughes TM, Hill D, Pattison W, Campbell P, Sander S, Van G, Tarpley J, Derby P, Lee R \& Boyle WJ. Osteoprotegerin: a novel secreted protein involved in the regulation of bone density. Cell 199789 309-319.

14 Tsuda E, Goto M, Mochizuki S, Yano K, Kobayashi F, Morinaga T \& Higashio K. Isolation of a novel cytokine from human fibroblasts that specifically inhibits osteoclastogenesis. Biochemical and Biophysical Research Communications 1997234 137-142.

15 Yasuda H, Shima N, Nakagawa N, Yamaguchi K, Kinosaki M, Mochizuki S, Tomoyasu A, Yano K, Goto M, Murakami A, Tsuda E, Morinaga T, Higashio K, Udagawa N, Takahashi N \& Suda T. Osteoclast differentiation factor is a ligand for osteoprotegerin/osteoclastogenesis-inhibitory factor and is identical to TRANCE/ RANKL. PNAS 199895 3597-3602.

16 Emery JG, McDonnell P, Burke MB, Deen KC, Lyn S, Silverman C, Dul E, Appelbaum ER, Eichman C, DiPrinzio R, Dodds RA, James IE, Rosenberg M, Lee JC \& Young PR. Osteoprotegerin is a receptor for the cytotoxic ligand TRAIL. Journal of Biological Chemistry 1998273 14363-14367.

17 Malyankar UM, Scatena M, Suchland KL, Yun TJ, Clark EA \& Giachelli CM. Osteoprotegerin is an alpha vbeta 3-induced, NFB-dependent survival factor for endothelial cells. Journal of Biological Chemistry 2000275 20959-20962.

18 Scatena M \& Giachelli C. The alpha(v)beta3 integrin, NF- $\kappa$ B, osteoprotegerin endothelial cell survival pathway. Potential role in angiogenesis. Trends in Cardiovascular Medicine 2002 12 83-88. 
19 Schoppet M, Preissner KT \& Hofbauer LC. RANK ligand and osteoprotegerin: paracrine regulators of bone metabolism and vascular function. Arteriosclerosis, Thrombosis, and Vascular Biology 200222 549-553.

20 Ugur-Altun B, Altun A, Gerenli M \& Tugrul A. The relationship between insulin resistance assessed by HOMA-IR and serum osteoprotegerin levels in obesity. Diabetes Research and Clinical Practice 200568 217-222.

21 Holecki M, Zahorska-Markiewicz B, Janowska J, Nieszporek T, Wojaczynska-Stanek K, Zak-Golab A \& Wiecek A. The influence of weight loss on serum osteoprotegerin concentration in obese perimenopausal women. Obesity 200715 1925-1929.

22 Zawadzki JK \& Dunaif A. Diagnostic criteria for polycystic ovary syndrome: towards a rational approach. In Polycystic Ovary Syndrome, pp 377-384. Eds A Dunaif, JR Givens, FP Haseltine \& GR Merriam, Boston: Blackwell Scientific Publications, 1992.

23 Escobar-Morreale HF, Sanchon R \& San Millan JL. A prospective study of the prevalence of nonclassic congenital adrenal hyperplasia (NCAH) among women presenting with hyperandrogenic symptoms and signs. Journal of Clinical Endocrinology and Metabolism 200893 527-533.

24 Hatch R, Rosenfield RL, Kim MH \& Tredway D. Hirsutism: implications, etiology, and management. American Journal of Obstetrics and Gynecology 1981140 815-830.

25 Bakhireva LN, Laughlin GA, Bettencourt R \& Barrett-Connor E. Does osteoprotegerin or receptor activator of nuclear factorkappaB ligand mediate the association between bone and coronary artery calcification? Journal of Clinical Endocrinology and Metabolism 200893 2009-2012.

26 Escobar-Morreale HF, Serrano-Gotarredona J, García-Robles R, Sancho J \& Varela C. Lack of an ovarian function influence on the increased adrenal androgen secretion present in women with functional ovarian hyperandrogenism. Fertility and Sterility 1997 $67654-662$.

27 Escobar-Morreale HF, Botella-Carretero JI, Alvarez-Blasco F, Sancho J \& San Millan JL. The polycystic ovary syndrome associated with morbid obesity may resolve after weight loss induced by bariatric surgery. Journal of Clinical Endocrinology and Metabolism 200590 6364-6369.

28 Vermeulen A, Verdonck L \& Kaufman JM. A critical evaluation of simple methods for the estimation of free testosterone in serum. Journal of Clinical Endocrinology and Metabolism 1999 84 3666-3672.

29 Matsuda M \& DeFronzo RA. Insulin sensitivity indices obtained from oral glucose tolerance testing: comparison with the euglycemic insulin clamp. Diabetes Care 199922 1462-1470.

30 Sandberg WJ, Yndestad A, Oie E, Smith C, Ueland T, Ovchinnikova O, Robertson AK, Muller F, Semb AG, Scholz H, Andreassen AK, Gullestad L, Damas JK, Froland SS, Hansson GK, Halvorsen B \& Aukrust P. Enhanced T-cell expression of RANK ligand in acute coronary syndrome: possible role in plaque destabilization. Arteriosclerosis, Thrombosis, and Vascular Biology 200626 857-863.

31 Kiechl S, Schett G, Schwaiger J, Seppi K, Eder P, Egger G, Santer P, Mayr A, Xu Q \& Willeit J. Soluble receptor activator of nuclear factor-kappa $\mathrm{B}$ ligand and risk for cardiovascular disease. Circulation $2007116385-391$.

32 Proudfoot D, Skepper JN, Hegyi L, Bennett MR, Shanahan CM \& Weissberg PL. Apoptosis regulates human vascular calcification in vitro: evidence for initiation of vascular calcification by apoptotic bodies. Circulation Research 200087 1055-1062.

33 Bennett BJ, Scatena M, Kirk EA, Rattazzi M, Varon RM, Averill M, Schwartz SM, Giachelli CM \& Rosenfeld ME. Osteoprotegerin inactivation accelerates advanced atherosclerotic lesion progression and calcification in older ApoE - / - mice. Arteriosclerosis, Thrombosis, and Vascular Biology 200626 2117-2124.

34 Bucay N, Sarosi I, Dunstan CR, Morony S, Tarpley J, Capparelli C, Scully S, Tan HL, Xu W, Lacey DL, Boyle WJ \& Simonet WS. Osteoprotegerin-deficient mice develop early onset osteoporosis and arterial calcification. Genes and Development 199812 $1260-1268$.
35 Price PA, June HH, Buckley JR \& Williamson MK. Osteoprotegerin inhibits artery calcification induced by warfarin and by vitamin D. Arteriosclerosis, Thrombosis, and Vascular Biology 200121 1610-1616.

36 Jono S, Ikari Y, Shioi A, Mori K, Miki T, Hara K \& Nishizawa Y. Serum osteoprotegerin levels are associated with the presence and severity of coronary artery disease. Circulation 2002106 1192-1194.

37 Schoppet M, Sattler AM, Schaefer JR, Herzum M, Maisch B \& Hofbauer LC. Increased osteoprotegerin serum levels in men with coronary artery disease. Journal of Clinical Endocrinology and Metabolism 200388 1024-1028.

38 Avignon A, Sultan A, Piot C, Mariano-Goulart D, Thuan Dit Dieudonne JF, Cristol JP \& Dupuy AM. Osteoprotegerin: a novel independent marker for silent myocardial ischemia in asymptomatic diabetic patients. Diabetes Care 200730 2934-2939.

39 Ziegler S, Kudlacek S, Luger A \& Minar E. Osteoprotegerin plasma concentrations correlate with severity of peripheral artery disease. Atherosclerosis $2005 \mathbf{1 8 2} 175-180$.

40 Guldiken B, Guldiken S, Turgut B, Turgut N, Demir M, Celik Y, Arikan E \& Tugrul A. Serum osteoprotegerin levels in patients with acute atherothrombotic stroke and lacunar infarct. Thrombosis Research 2007120 511-516.

41 Abedin M, Omland T, Ueland T, Khera A, Aukrust P, Murphy SA, Jain T, Gruntmanis U, McGuire DK \& de Lemos JA. Relation of osteoprotegerin to coronary calcium and aortic plaque (from the Dallas Heart Study). American Journal of Cardiology 200799 513-518.

42 Omland T, Ueland T, Jansson AM, Persson A, Karlsson T, Smith C, Herlitz J, Aukrust P, Hartford M \& Caidahl K. Circulating osteoprotegerin levels and long-term prognosis in patients with acute coronary syndromes. Journal of the American College of Cardiology 200851 627-633.

43 Zauli G, Corallini F, Bossi F, Fischetti F, Durigutto P, Celeghini C, Tedesco F \& Secchiero P. Osteoprotegerin increases leukocyte adhesion to endothelial cells both in vitro and in vivo. Blood 2007 $110536-543$.

44 Mangan SH, Campenhout AV, Rush C \& Golledge J. Osteoprotegerin upregulates endothelial cell adhesion molecule response to tumor necrosis factor-alpha associated with induction of angiopoietin-2. Cardiovascular Research 200776 494-505.

45 Saika M, Inoue D, Kido S \& Matsumoto T. $17 \beta$-Estradiol stimulates expression of osteoprotegerin by a mouse stromal cell line, ST-2, via estrogen receptor-alpha. Endocrinology $2001 \mathbf{1 4 2}$ 2205-2212.

46 Hofbauer LC, Khosla S, Dunstan CR, Lacey DL, Spelsberg TC \& Riggs BL. Estrogen stimulates gene expression and protein production of osteoprotegerin in human osteoblastic cells. Endocrinology 1999140 4367-4370.

47 Khosla S, Atkinson EJ, Dunstan CR \& O'Fallon WM. Effect of estrogen versus testosterone on circulating osteoprotegerin and other cytokine levels in normal elderly men. Journal of Clinical Endocrinology and Metabolism 200287 1550-1554.

48 Hofbauer LC, Hicok KC, Chen D \& Khosla S. Regulation of osteoprotegerin production by androgens and anti-androgens in human osteoblastic lineage cells. European Journal of Endocrinology $2002147269-273$.

49 Chen Q, Kaji H, Kanatani M, Sugimoto T \& Chihara K. Testosterone increases osteoprotegerin mRNA expression in mouse osteoblast cells. Hormone and Metabolic Research 200436 674-678.

50 Szulc P, Hofbauer LC, Heufelder AE, Roth S \& Delmas PD. Osteoprotegerin serum levels in men: correlation with age, estrogen, and testosterone status. Journal of Clinical Endocrinology and Metabolism 200186 3162-3165.

51 Kim SM, Lee J, Ryu OH, Lee KW, Kim HY, Seo JA, Kim SG, Kim NH, Baik SH, Choi DS \& Choi KM. Serum osteoprotegerin levels are associated with inflammation and pulse wave velocity. Clinical Endocrinology $200563594-598$.

52 Indridason OS, Franzson L \& Sigurdsson G. Serum osteoprotegerin and its relationship with bone mineral density and markers of bone turnover. Osteoporosis International $200516417-423$. 
53 Yano K, Tsuda E, Washida N, Kobayashi F, Goto M, Harada A, Ikeda K, Higashio K \& Yamada Y. Immunological characterization of circulating osteoprotegerin/osteoclastogenesis inhibitory factor: increased serum concentrations in postmenopausal women with osteoporosis. Journal of Bone and Mineral Research 199914 518-527.

54 Noyan V, Yucel A \& Sagsoz N. The association of bone mineral density with insulin resistance in patients with polycystic ovary syndrome. European Journal of Obstetrics, Gynecology and Reproductive Biology 2004115 200-205.
55 Good C, Tulchinsky M, Mauger D, Demers LM \& Legro RS. Bone mineral density and body composition in lean women with polycystic ovary syndrome. Fertility and Sterility $1999 \mathbf{7 2}$ $21-25$.

Received 10 June 2008

Accepted 14 June 2008 